(C) 2014

\author{
Яремич Н. В., молодший науковий співробітник
}

Черкаська дослідна станція біоресурсів НААН

\title{
РЕАЛІЗАЦІЯ ВІДТВОРЮВАЛЬНОЇ ЗДАТНОСТІ САМОК НОРОК СКАНДИНАВСЬКОГО ТИПУ СЕЛЕКЦІЇ ЗАЛЕЖНО ВІД РІВНЯ ВГОДОВАНОСТІ
}

\section{Рецензент - кандидат сільськогосподарських наук О. М. Гаврии}

Проведено дослідження показників відтворювальної здатності самок норок різних генотипів скандинавської селекції залежно від їх рівня вгодованості на час підготовки до сезону парувань. По групам норок генотипів Scanglow ma Pearl максимальні значення плідності зареєстровані у самок з індексом вгодованості 23-25, а для звірів кольорового типу Scanblack даний показник максимальним був за умови збільшення рівня вгодованості до індексу 26-28. Встановлено, щуо збільшення індексу вгодованості у звірів скандинавського коричневого типу забарвлення корелює $i$ зі зниженням показника частки народжених мертвих норченят, а для норок перл характерним є збільшення розміру гнізда зі зниженням вгодованості самок.

Ключові слова: норка, генотип, кольоровий тип, плодючість, відтворювальна здатність, кондиція, вгодованість, щуеніння.

Постановка проблеми. У практиці розведення сільськогосподарських тварин значна увага надається вгодованості. Розроблені відповідні методики й показники, що дають змогу визначити їі рівень. У галузі хутрового звірівництва, передусім норківництва, публікації, які зустрічаються, носять загальний характер й більш детально розкривають питання годівлі. Також слід відмітити, що дослідження в цьому напрямі проводилися в основному на норках вітчизняної селекції. Стосовно ж норок скандинавських генотипів інформація майже відсутня.

Аналіз основних досліджень і публікацій, у яких започатковано розв'язання проблеми. Важливе значення в розмноженні та підготовці до нього відіграє вгодованість звірів, яка виражається відношенням маси тіла до його довжини. На основі отриманих індексів можна оцінити кондицію тварини в даний виробничий період. Результати розмноження самок норок в умовах звірогосподарства багато в чому залежать від рівня їх вгодованості перед гоном. Дослідження, проведені на значній кількості норок різних генотипів, виявили, що самки норок на кінець лютого вже повинні мати заводську кондицію, тобто індекс вгодованості повинен бути не менше 23 і не більше 27 [1, 6]. Більшість науковців відзначає, що серед самок із надмірною вагою й рівнем вгодованості вище середнього реєструється більше особин зі зниженою плодючістю, збільшується відсоток мертвонароджених щенят, у самок спостерігається нестача молока, i, як наслідок, - високий відхід молодняку. В більшості публікацій вказується, що в результаті наближення самок до оптимальної вгодованості середній вихід молодняку на самку підвищується на 0,5-0,7 гол. порівняно з попередніми роками (без урегулювання вгодованості) або з контрольними групами, яких надмірно годували в січні-лютому $[2,5]$.

Метою досліджень $є$ вивчення відтворювальної здатності самок норок кольорових типів Scanglow, Scanblack, Pearl різного ступеня вгодованості та встановлення оптимальних показників індексів для окомірної оцінки й відбору еталонних звірів даних генотипів в умовах вітчизняних звірогосподарств.

Завдання досліджень - визначити вплив рівня вгодованості самок скандинавського типу селекції на результати реалізації репродуктивного потенціалу в умовах звірогосподарства Центрального регіону України.

Матеріал і методика проведення досліджень. Вивчення впливу рівня вгодованості самок скандинавського типу селекції проводилося на базі ТОВ «Золотоніське звірогосподарство» Золотоніського району Черкаської області. Для проведення дослідження сформували три групи тварин Scanglow, Scanblack, Pearl (по 123 гол. у кожній групі). Зважування та взяття лінійних промірів проводили в період підготовки до проведення сезону парувань (лютий). Рівень вгодованості самок визначали на основі розрахунку співвідношення довжини тіла до їх живої маси за формулою [4]:

$$
I=\frac{B}{\partial}
$$

де: $I$ - індекс вгодованості; в - жива маса, г; $\partial-$ довжина тіла, см.

Рівень відтворювальної здатності визначали за показниками статевої активності самок під час проведення сезону парувань, кількісними та які- 


\section{СІЛЬСЬКЕ ГОСПОДАРСТВО. ТВАРИННИЦТВО}

сними характеристиками гнізд на основі звітної документації по господарству (форма звітності 6-3В і журнали з бонітування).

Результати досліджень. Вивчення таких показників екстер'єру звірів як довжина тіла, жива маса та індекс вгодованості самок норок у період підготовки та проведення гону дає змогу стверджувати, що звірі мали порівняно невисоку мінливість за даною ознакою (2,13-9,12 \%). Середній показник довжини тіла тварин досліджуваних груп знаходився в межах 39-42 см, живої маси - 759-1200 г, а розрахований індекс вгодованості, відповідно, 19-29. У даному господарстві завдяки проведеній ретельній роботі зоотехніків та доглядачів самки норок мали заводську кондицію на момент початку сезону розмноження, про що свідчить відсутність вірогідної різниці в порівнянні середніх значень досліджуваних показників $(\mathrm{P}<0,95)$.

Досліджуючи групи норок за рівнем вгодованості перед гоном (див. рис.) встановлено, що переважна більшість самок генотипу Scanglow мала відповідний індекс у межах 22-27 (84,55 \%). Аналогічна ситуація спостерігалась і по групі норок Scanblack, - більшість самок характеризувалися індексом вгодованості, як і в попередній групі тварин 22-27 (68,29 \%). По групі самок генотипу Pearl значна частка самок $(9,60-$ $17,60 \%$ ) мали індекси вгодованості 22-28, максимальний відсоток самок по групі характеризувався індексом вгодованості 24 (89,6 \%).

Дослідження, проведені на вітчизняних норках, дають змогу стверджувати, що оптимальною на початок сезону парування $є$ кондиція самок, за якої індекс вгодованості становить 24-26 [3, 5, 7].

Досліджуючи вплив вгодованості самок скандинавської селекції на їх статеву активність (табл. 1) встановлено, що зі збільшенням значення індексу у самок норок групи Scanglow відмічено тенденцію до зростання показника кількості періодів статевої охоти за сезон розмноження на 0,12 зареєстрованих випадків, періоди-

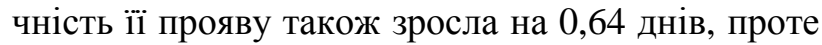
у порівнянні середніх значень різниця за показниками виявилася невірогідною $(\mathrm{P}<0,95)$. За показником кратності покриття не відмічено вірогідної різниці, в тім мінімальне значення показника зареєстровано по групі самок, індекс вгодованості яких становив 23-25, а максимальне - по групі тварин з індексом 26-27.

Характеризуючи перебіг сезону розмноження групи короткошерстих норок Scanblack відмічено обернену тенденцію за таким показником як періодичність статевої охоти. Встановлено, що зі збільшенням індексу вгодованості самок знижується інтервал між проявами статевої охоти в середньому на 0,23-0,42 днів ( $<<0,95)$. Встановлено також, що зі збільшенням індексу вгодованості до 26-28 спостерігалась максимальна кратність покриття самок. По групі Pearl періодичність прояву статевої охоти варіювала в межах 7-11 днів, мінімальним дане значення зареєстровано у самок із відповідними індексами 20-22, а максимальне - 23-25. Крім того слід зазначити, що незалежно від генотипової належності, спостерігались поодинокі випадки самок, які не дали приплоду, з індексом вгодованості 29.

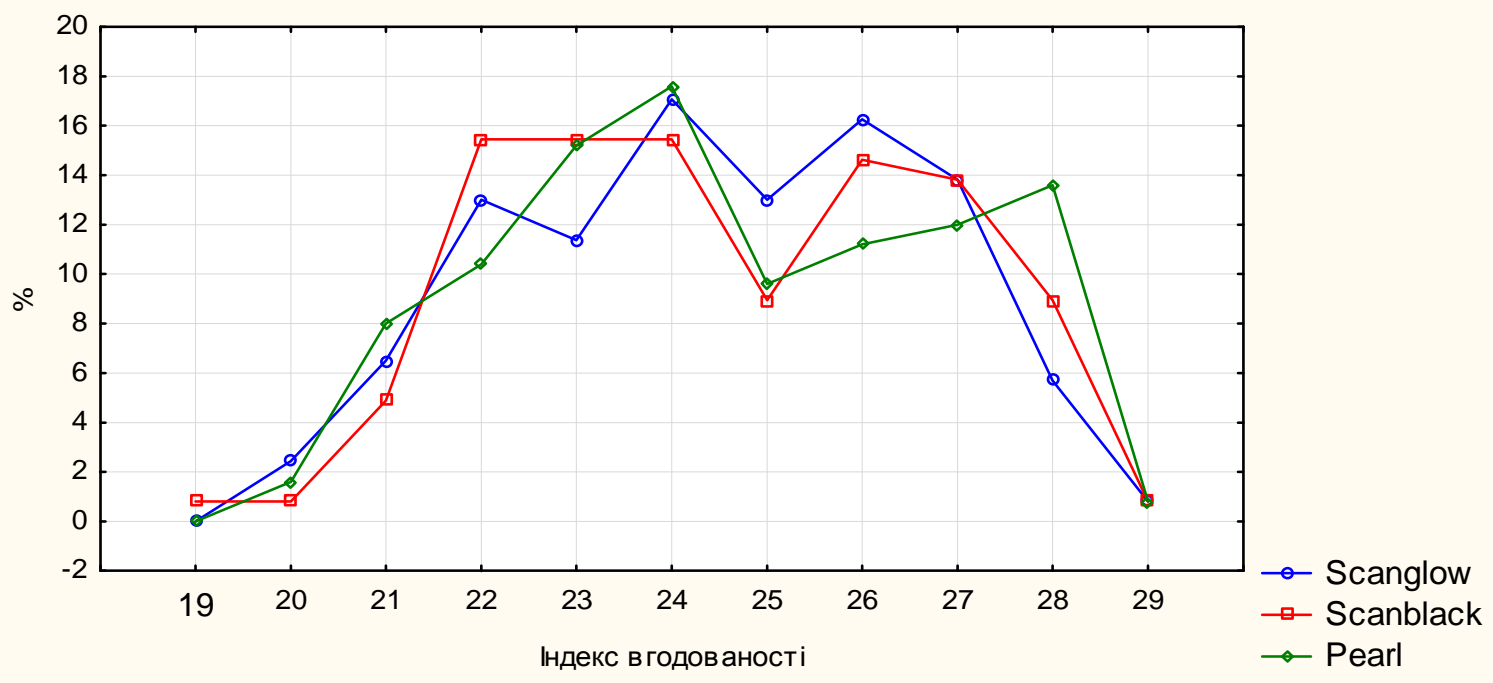

Рис. Розподіл самок норок скандинавського типу селекції за показником індексу вгодованості 
СІЛЬСЬКЕ ГОСПОДАРСТВО. ТВАРИННИЦТВО

\section{1. Результати перебігу сезону парувань самок норок різних генотипів}

\begin{tabular}{|c|c|c|c|c|c|}
\hline Генотип & $\begin{array}{c}\text { Індекс } \\
\text { вгодованості } \\
\text { самок } \\
\end{array}$ & $\mathrm{N}$ & $\begin{array}{c}\text { Кількість періодів } \\
\text { статевої охоти }\end{array}$ & $\begin{array}{c}\text { Періодичність про- } \\
\text { яву статевої охоти, } \\
\text { днів } \\
\end{array}$ & $\begin{array}{c}\text { Кратність } \\
\text { покриття самок }\end{array}$ \\
\hline \multirow{6}{*}{ 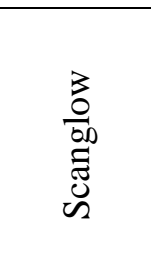 } & $\leq 19$ & 0 & 0 & 0 & 0 \\
\hline & $20-22$ & 26 & $1,81+0,08$ & $8,05+0,33$ & $2,73+0,10$ \\
\hline & $23-25$ & 51 & $1,86+0,05$ & $8,11+0,27$ & $2,69+0,09$ \\
\hline & $26-28$ & 45 & $1,93+0,04$ & $8,69+0,35$ & $2,78+0,08$ \\
\hline & $\geq 29$ & 1 & 0 & 0 & 0 \\
\hline & По групі & 123 & $1,87+0,03$ & $8,33+0,19$ & $2,77+0,05$ \\
\hline \multirow{6}{*}{ 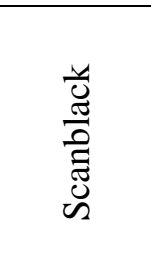 } & $\leq 19$ & 1 & 0 & 0 & 0 \\
\hline & $20-22$ & 26 & $1,92+0,05$ & $8,04+0,32$ & $2,92+0,12$ \\
\hline & $23-25$ & 49 & $1,86+0,05$ & $7,62+0,17$ & $2,82+0,10$ \\
\hline & $26-28$ & 46 & $1,91+0,04$ & $7,81+0,22$ & $3,00+0,10$ \\
\hline & $\geq 29$ & 1 & 0 & 0 & 0 \\
\hline & По групі & 123 & $1,89+0,03$ & $7,78+0,13$ & $2,91+0,06$ \\
\hline \multirow{6}{*}{ एँ } & $\leq 19$ & 0 & 0 & 0 & 0 \\
\hline & $20-22$ & 25 & $1,84+0,07$ & $7,86+0,32$ & $2,92+0,15$ \\
\hline & $23-25$ & 53 & $1,82+0,05$ & $8,24+0,31$ & $2,90+0,11$ \\
\hline & $26-28$ & 49 & $1,81+0,06$ & $8,13+0,27$ & $3,02+0,11$ \\
\hline & $\geq 29$ & 1 & 0 & 0 & 0 \\
\hline & По групі & 123 & $1,82+0,03$ & $8,12+0,17$ & $2,94+0,07$ \\
\hline
\end{tabular}

Тривалість ембріогенезу у самок досліджуваних генотипів знаходився в межах 36-63 днів із середнім рівнем варіювання ознаки (C.V., \% = 10,1-13,4). У досліджуваних групах даний показник мав середнє значення 46,7-48,1 днів, вірогідної різниці не встановлено $(\mathrm{P}<0,95)$. Результати щеніння самок норок різних генотипів наведено в таблиці 2. 3 отриманих даних видно, що у норок Scanglow максимальним показник числа народжених норченят виявився по групі самок з індексом вгодованості 2325 і становив 4,12 голів на самку, що брала участь у розмноженні. Різниця в порівнянні з самками, індекс яких становив 20-22, була 0,89 гол., хоча виявилася невірогідною $(\mathrm{P}<0,95)$. Характеризуючи якісні характеристики гнізд варто зауважити, що самки 3 середнім рівнем вгодованості мали максимальні значення показника нороджених живих норченят, який переважав аналогів на 0,88-0,95 голів $(\mathrm{P}<0,95)$. За показником числа мертвонароджених норченят відмічено обернену тенденцію - самки 3 високими значеннями індексу мали мінімальне середнє значення за досліджуваним показником, яке становило лише 0,26 гол, проти $0,42-0,43$ гол. по решті самок у середині даної кольорової групи. Мінімальний відсоток безплідних самок зареєстровано у представниць із середнім індексом вгодованості - 29,4\%, а максимальний $(37,8 \%)$ - у самок, відповідний індекс яких становив 26-28.

Показник плідності по кольоровій групі Scanblack у середньому дорівнював 2,89 голів, у середині групи показник знаходився в межах 0-3,17 голів. Максимальне значення відмічено у самок із високим рівнем вгодованості (індекс 26-28) із перевагою у 0,05-1,02 гол. порівняно 3 аналогічним показником решти самок $(\mathrm{P}<0,95)$. За показником кількості народжених живих норченят відмічено аналогічну тенденцію. Наведені дані свідчать, що у самок із високим рівнем вгодованості (індекс 26-28) спостерігалося і максимальне число мертвонароджених норченят - 0,37 гол. (проти 0,27 у решті груп). Варто також зазначити, що спостерігалася зворотна тенденція за показником частки безплідних самок із зростанням рівня їх вгодованості.

По групі норок генотипу Pearl максимальні показники плідності мали самки з індексом 23-25 - 4,43 гол., що на 1,14-2,15 гол. вище аналогічних показників $(\mathrm{P}>0,95 \ldots 0,999)$. За показником кількості народжених живих норченят дана група також мала вірогідну перевагу над рештою самок на 1,12-2 гол. (P>0,95...0,999). Кількість мертвонароджених норченят варіювала в межах 0,32-0,47 голів; на самку, яка брала участь у розмноженні, максимальне значення відмічено у самок з індексом вгодованості 26-28. Дослідження рівня безпліддя самок дає змогу стверджувати, що максимальна частка таких самок $(52,0 \%)$ мала індекс вгодованості 20-22, а мінімальні - тварини з індексом 23-25 (22,6\%); $100 \%$ безпліддя відмічено у самки з індексом вгодованостi 29. 
СІЛЬСЬКЕ ГОСПОДАРСТВО. ТВАРИННИЦТВО

\section{2. Показники відтворювальної здатності самок різних генотипів}

\begin{tabular}{|c|c|c|c|c|c|c|}
\hline \multirow[b]{2}{*}{ Генотип } & \multirow{2}{*}{$\begin{array}{c}\text { Індекс } \\
\text { вгодованості } \\
\text { самок }\end{array}$} & \multirow[b]{2}{*}{$\mathrm{N}$} & \multirow{2}{*}{$\begin{array}{c}\text { Плідність } \\
\text { самок, які брали } \\
\text { участь } \\
\text { у розмноженні, } \\
\text { гол. }\end{array}$} & \multicolumn{2}{|c|}{$\begin{array}{c}\text { Отримано молодняку, } \\
\text { в т. ч.: }\end{array}$} & \multirow{2}{*}{$\begin{array}{c}\text { \% самок } \\
\text { без при- } \\
\text { плоду }\end{array}$} \\
\hline & & & & $\begin{array}{c}\text { живих } \\
\text { норченят, гол. }\end{array}$ & $\begin{array}{c}\text { мертвих } \\
\text { норченят, } \\
\text { гол. }\end{array}$ & \\
\hline \multirow{6}{*}{ 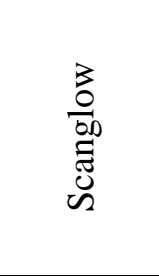 } & $\leq 19$ & 0 & 0 & 0 & 0 & 0 \\
\hline & $20-22$ & 26 & $3,23+0,47$ & $2,81+0,44$ & $0,42+0,14$ & 30,77 \\
\hline & $23-25$ & 51 & $4,12+0,44$ & $3,69+0,40$ & $0,43+0,12$ & 29,41 \\
\hline & $26-28$ & 45 & $2,94+0,41 *$ & $2,68+0,38$ & $0,26+0,11$ & 37,78 \\
\hline & $\geq 29$ & 1 & 0 & 0 & 0 & 100,00 \\
\hline & По групі & 123 & $3,48+0,26$ & $3,12+0,24$ & $0,36+0,07$ & 33,33 \\
\hline \multirow{6}{*}{ 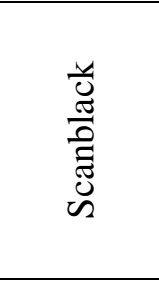 } & $\leq 19$ & 1 & 0 & 0 & 0 & 1000 \\
\hline & $20-22$ & 26 & $2,15+0,44$ & $1,88+0,41$ & $0,27+0,12$ & 46,15 \\
\hline & $23-25$ & 49 & $3,12+0,39$ & $2,68+0,36$ & $0,27+0,09$ & 36,73 \\
\hline & $26-28$ & 46 & $3,17+0,42$ & $2,80+0,40$ & $0,37+0,12$ & 34,78 \\
\hline & $\geq 29$ & 1 & 0 & 0 & 0 & 100,00 \\
\hline & По групі & 123 & $2,89+0,24$ & $2,59+0,23$ & $0,30+0,06$ & 39,02 \\
\hline \multirow{6}{*}{ בٓ } & $\leq 19$ & 0 & 0 & 0 & 0 & 0 \\
\hline & $20-22$ & 25 & $2,28+0,51 * * *$ & $1,96+0,46^{* * *}$ & $0,32+0,18$ & 52,00 \\
\hline & $23-25$ & 53 & $4,43+0,39$ & $3,96+0,36$ & $0,47+0,13$ & 22,64 \\
\hline & $26-28$ & 49 & $3,29+0,33 *$ & $2,84+0,32 *$ & $0,45+0,12$ & 24,49 \\
\hline & $\geq 29$ & 1 & 0 & 0 & 0 & 100,00 \\
\hline & По групі & 123 & $3,54+0,24$ & $3,11+0,22$ & $0,43+0,08$ & 28,00 \\
\hline
\end{tabular}

Примітка: *- ${ }^{*}>0,95 ; * * *-\mathrm{P}>0,999$

3 метою встановлення залежності між рівнем вгодованості самок та їх репродуктивною функцією нами проведено кореляційний аналіз. Розраховані дані свідчать про різний рівень зв'язку між досліджуваними генотипами. По групі самок Scanglow значення коефіцієнта кореляції знаходилися в межах 0,34-0,12. Вірогідним зв'язок виявися між показниками вгодованості та числом народжених мертвими норченят, тобто, зі збільшенням рівня вгодованості самок вірогідно зменшується частка мертвонароджених щенят у гніздах. Для самок Scanblack не встановлено вірогідного зв'язку між досліджуваними ознаками. Для самок генотипу Pearl коефіцієнти кореляції мали вірогідні значення, а їх зворотна направленість засвідчує, що збільшення вгодованості самок має негативне вираження в реалізації відтворювальної здатності.

\section{БІБЛІОГРАФІЯ}

1. Берестов В. А. Звероводство. / Учебное пособие / В. А. Берестов - СПб. : Лань, 2002. - 480 с.

2. Воспроизводительная способность норок в зависимости от веса и упитанности / Кузнецов Г. А., Евреинов А. Г., Цепков Н. М., Куличков Б. А., Померанцев В. В. // Кролиководство и звероводство. - 1974. - № 6. - С. 23-25.
Висновок. За результатами проведених досліджень встановлено, що самки різного типу забарвлення в умовах ТОВ «Золотоніське звірогосподарство» залежно від кондиції на початок сезону парування мали різні показники відтворювальної здатності. Максимальні значення плідності зареєстровані у самок з індексом вгодованості 23-25, проте для тварин чорного типу забарвлення даний показник був максимальним за умови збільшення рівня вгодованості до індексу 26-28; порівнюючи значення всередині групи різниця виявилася невірогідною $(\mathrm{P}<0,95)$. Визначено також, що збільшення індексу вгодованості у звірів скандинавського коричневого типу забарвлення корелює і зі зниженням показника частки народжених мертвих норченят, а для норок перл характерним $є$ збільшення розміру гнізда зі зниженням вгодованості самок.

3. Гавриш О. М. Роль селекційно-генетичних факторів у формуванні продуктивності норок різних типів : автореф. дис. ... канд. с.-г. наук. Чубинське, 2011. - 20 с.

4. Зайцев О. Г. Звірівництво / О. Г. Зайцев. К. : Урожай, 1984. - 120 с.

5. Осташевський В. I. Вплив живої маси, вго- 


\section{СІЛЬСЬКЕ ГОСПОДАРСТВО. ТВАРИННИЦТВО}

дованості та спаровування норок в окремі періоди статевої охоти на їх багатоплідність / В. І. Осташевський, 3. С. Щербатий, Б. А. Павлів // Науковий вісник Львівської національної академії ветеринарної медицини ім. С. З. Гжицького. - 2005. - Т. 7 (№ 2). - Ч. 3. - С. 202-209.
6. Перельдик Н. Ш. Кормление пушных зверей / Н. Ш. Перельдик, Л. В. Милованов, А. Т. Ерин. М. : ВО «Агропромиздат», 1987. - 350 с.

7. Цупило О. А. Вплив природних та індукованих факторів на резистентність та відтворну здатність норок : автореф. дис. ... канд. вет. наук. - Харків, 2001. - 18 с. 